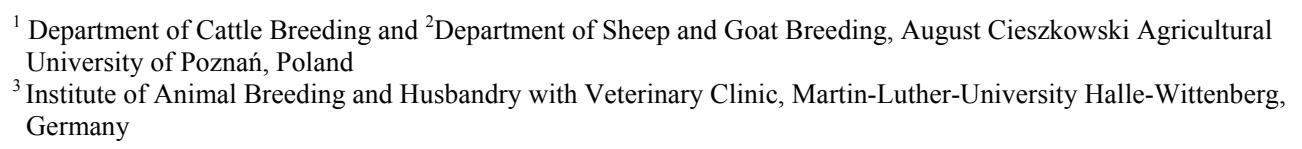

RYSZARD SKRZYPEK ${ }^{1}$, JACEK WÓJTOWSKI ${ }^{2}$ and ROLF-DIETER FAHR ${ }^{3}$

\title{
Hygienic quality of cow bulk tank milk depending on the method of udder preparation for milking (short communication)
}

\begin{abstract}
The investigations were carried out in the year 2001 on 167 Black-and-White cattle farms of Wielkopolska region (West Poland). On the farms included in the study a survey on performing the premilking procedures was conducted and the results were collected concerning analyses of bulk tank milk samples for the somatic cell count (SCC) and total microorganism count (TMC). Herds, in which udders and teats were cleaned with a towel soaked with a disinfectant or washed with water containing a disinfectant, were characterized by $\operatorname{lowest}_{\log } \mathrm{SCC}$ (12.36 and 12.41, respectively). They were followed by herds in which wiping with a dry towel (12.48) and washing with clean water (12.58) were practiced. The lowest $\log _{\mathrm{e}} \mathrm{TMC}$ was observed in the herds in which udders and teats were cleaned with a dry towel (10.66). This characteristic was similar in the herds where washing with clean water or wiping with a towel soaked with a disinfectant were practiced (10.89 and 11.00, respectively). The highest value of $\log _{\mathrm{e}} \mathrm{TMC}$ was in the herds in which washing with water containing a disinfectant was practiced (11.28). For SCC, a significant interaction was found between both pre-milking procedures. In the case of wiping with either a dry or wet towel, significantly lower values of $\log _{\mathrm{e}} \mathrm{SCC}$ were observed in the herds in which forestripping was performed prior to cleaning. However, in the herds in which udders and teats were washed with water, a better option was to perform forestripping after udder and teat cleaning.
\end{abstract}

Key Words: cow milk, hygienic quality, udder preparation

\section{Zusammenfassung}

Titel der Arbeit: Einfluss der Eutervorbereitung vor dem Melken auf die hygienische Qualität von Kuhsammelmilch (Kurzmitteilung)

Die Untersuchungen wurden im Jahr 2001 in 167 Herden des Schwarzbunten Rindes in der Wielkopolska Region (Westpolen) durchgeführt. Während einer Betriebsbesichtigung wurden mittels eines Fragebogens die Teilschritte bei der Eutervorbereitung für das Melken erfasst. Es wurde auch der Gehalt an somatischen Zellen (SCC) und die durchschnittliche Keimzahl (TMC) der während des gesamten Jahres erfassten Sammelmilchproben analysiert. Die niedrigsten $\log (\mathrm{SCC})$-Werte wurden in den Herden ermittelt, die für die Euter- und Zitzenreinigung entweder mit Desinfektionsmittel durchtränkte Tücher oder mit Desinfektionsmittel versetztes Wasser verwendeten (12,36 bzw. 12,41), gefolgt von den Herden, in denen die Euter mit trockenem Tuch abgewischt $(12,48)$ bzw. in denen mit Wasser ohne Desinfektionsmittel gereinigt wurde $(12,58)$. Der niedrigste $\log (\mathrm{TMC})$-Wert wurde in den Herden beobachtet, wo Euter und Zitzen mit trockenem Tuch abgewischt wurden $(10,66)$. Ähnliche durchschnittliche Keimzahlen der Sammelmilch sind in den Betrieben festgestellt worden, in denen eine Euterreinigung durch Waschen mit Wasser ohne Desinfektionsmittel oder mittels Tuch mit Desinfektionsmittel praktiziert wurde und die Werte von 10,89 bzw. 11,00 erreichten. Dagegen wurde der höchste $\log (\mathrm{TMC})$-Wert in den Betrieben festgestellt, die Wasser mit Desinfektionsmittel zur Reinigung nutzten $(11,28)$. Zwischen beiden Methoden trat eine signifikante Interaktion auf. Beim Reinigen mit trockenem oder feuchtem Tuch ergaben sich signifikant niedrigere $\log (\mathrm{SCC})$-Werte, wenn das Vormelken vor der Euterreinigung durchgeführt wurde. Wurden demgegenüber Euter und Zitzen vor dem Melken mit Wasser gewaschen, wurden dann bessere Ergebnisse erzielt, wenn das Vormelken nach der Reinigung erfolgte.

Schlüsselwörter: Kuhmilch, hygienische Qualität, Eutervorbereitung 


\section{Introduction}

Major determinants of the hygienic quality of milk are the concentrations of somatic cells and microorganisms (HEESCHEN, 1997), and proper udder and teat preparation for milking is the primary condition that has to be fulfilled for the production of milk of high hygienic standard, i.e., with low concentration of both constituents. Practices, which are considered advisable before each milking are forestripping, and udder and teat cleaning. Forestripping is recommended due to the fact that prior to milking, the highest concentration of somatic cells and microorganisms is in the milk of the teat cistern (HARMON, 1994; FAHR, 2002). Thus, the removal of this milk results in significant reduction in the counts of these elements in the milked milk. At the same time, forestripping facilitates prompt identification of the clinical form of mastitis in individual quarters and immediate treatment of diseased cows and their milking using a separate equipment. For these reasons, and as a result of separating the milk of healthy cows from that of diseased cows, the somatic cell and microorganism counts in bulk tank milk are reduced (MERILL et al., 1987; PANKEY, 1989; GILL et al., 1990; RASMUSSEN, 2000; BARRETT, 2002; SKRZYPEK, 2002a; WAGNER and RUEGG, 2002). In the European Union countries, regulations are in force (EEC DIRECTIVE 89/362), which impose on the farmer the obligation to perform the visual appraisal of forestripped milk prior to each milking. Apart from the diagnostic and hygienic effect, forestripping is also a very strong stimulus causing the ejection of milk, necessary for the proper course of the milking process (RASMUSSEN, 2000).

In turn, cleaning the udder and teats before milking is strongly recommended as at that time the skin of both parts of the body is dirtied and contaminated with microorganisms to the highest degree. For this reason, udder and teat cleaning is the most important method preventing the contamination of milk after milking. Moreover, it is the most effective measure to prevent the infection of the udder with environmental microorganisms (GALTON et al., 1986; GILL et al., 1990; PANKEY and DRECHSLER, 1993; SMITH and HOGAN, 1993; RASMUSSEN, 2000). Similarly to forestripping, udder and teat cleaning is a significant stimulus triggering the release of sufficient amounts of oxytocin and the ejection of milk from the glandular tissue to the udder cistern (BRUCKMAIER and BLUM, 1998).

In spite of the common acceptance of both procedures outlined above, literature does not supply unambiguous information concerning their optimal application. Particularly, literature is not consistent as far as the sequence of their adoption. For instance, MERRIL et al. (1987) and WAGNER and RUEGG (2002) suggest forestripping before udder and teat cleaning, whilst PANKEY (1989) claims that performing these procedures in the reverse order is a better option.

The aim of this study was to determine both the effect of the sequence of the forestripping procedure in relation to udder and teat cleaning and the effect of the method of udder and teat cleaning prior to milking on somatic cell count and total microorganism count in bulk tank milk. The purpose was also to investigate the interaction between both procedures of preparing the udder and teats for milking.

\section{Material and methods}

The investigations were carried out in the year 2001 on 167 Polish dairy farms located in the Wielkopolska region (Western Poland). The average number of cows in the herd was 24.8 animals (ranging from 6 to 345 cows). All the herds consisted of Black-and- 
White cows, which were milked twice a day. In the farms subjected to analysis a survey was conducted during visits, the aim of which was to determine the method of preparing the udder and teats for milking. Apart from that, using laboratory data the results of the readings of bulk tank milk samples for somatic cell count (SCC) and total microorganism count (TMC) were collected for the whole analyzed year. These samples were taken during the collection of milk by the dairy plant. SCC was determined once a month using a Fossomatic cell counter (Foss Electric, Hillerød, Denmark), while TMC was determined twice a month with a standard plate count method. For the statistical analysis, monthly weighted means were calculated for TMC.

The data were analyzed statistically using the multi-factorial analysis of variance with the SAS package (SAS, 1996). Before the calculations were performed, the input values for SCC and TMC were transformed using the natural logarithm. The following effects were included in the statistical model: sequence of the forestripping procedure in relation to the udder and teat cleaning (before or after), method of udder and teat cleaning (dry towel, wet towel soaked with a disinfectant, clean water, water with the addition of a disinfectant), interaction between the sequence of forestripping and the method of udder and teat cleaning, month $(1, \ldots, 12$; repeated variable), and mean number of cows in the herd (regression). The results are presented with the least squares means (LSM) and standard errors (SE).

\section{Results}

Table 1 shows that the frequency of application of the particular premilking procedures was very similar amongst the investigated herds. Generally, the sequence of forestripping did not affect the SCC and TMC values. The lowest SCC was observed in the herds where udders and teats were cleaned by wiping with a towel soaked with a disinfectant or washed with water containing a disinfectant. However, the highest SCC was found in the herds in which washing with clean water was adopted. The lowest TMC was found in the herds in which udders and teats were cleaned using a dry cloth, then TCM was similar in the herds where wiping with a wet cloth or washing with clean water was adopted, while the highest value of this characteristic was found in the herds where water containing a disinfectant was used.

Table 1

The effect of the method of forestripping and udder and teat cleaning before milking on somatic cell count (SCC) and total microorganism count (TMC) in $1 \mathrm{ml}$ of milk [Der Einfluss der Methode des Vormelkens und der Zitzen- und Euterreinigung auf den Gehalt an somatischen Zellen (SCC) und die durchschnittliche Keimzahl (TMC) in $1 \mathrm{ml} \mathrm{der} \mathrm{Milch]}$

\begin{tabular}{|c|c|c|c|c|c|c|}
\hline \multirow[b]{2}{*}{ Item } & & \multirow{2}{*}{$\begin{array}{l}\text { Number } \\
\text { of herds }\end{array}$} & \multicolumn{2}{|c|}{$\log _{\mathrm{e}} \mathrm{SCC}$} & \multicolumn{2}{|c|}{$\log _{\mathrm{e}} \mathrm{TMC}$} \\
\hline & & & LSM & $\mathrm{SE}$ & LSM & $\mathrm{SE}$ \\
\hline Forestripping is performed before udder & Yes & 84 & 12.45 & 0.02 & 10.97 & 0.03 \\
\hline and teat cleaning & No & 83 & 12.47 & 0.02 & 10.95 & 0.03 \\
\hline $\begin{array}{l}\text { Method of udder and teat cleaning } \\
\text { before milking: }\end{array}$ & & & & & & \\
\hline dry towel & & 40 & $12.48 \mathrm{~A}$ & 0.02 & $10.66 \mathrm{~A}$ & 0.04 \\
\hline wet towel with a disinfectant, dry towel & & 40 & $12.36 \mathrm{~B}$ & 0.02 & 11.00B & 0.04 \\
\hline clean water, dry towel & & 47 & $12.58 \mathrm{C}$ & 0.02 & $10.89 \mathrm{~B}$ & 0.04 \\
\hline water containing a disinfectant, dry towel & & 40 & $12.41 \mathrm{~B}$ & 0.02 & $11.28 \mathrm{C}$ & 0.05 \\
\hline
\end{tabular}


The interaction between the sequence of forestripping and the method of cleaning the udder and teats had a significant and considerable effect on SCC, whereas no such effect was observed on TMC (Table 2). In the case of both methods of wiping the udder and teats, a significantly lower level of SCC was observed in the farms in which forestripping was practiced as the first procedure. However, in the case of washing with water a lower SCC level was found in the herds where forestripping was performed after washing. This difference was larger in the herds in which water with a disinfectant was used compared with the herds where the plain water was used.

\section{Table 2}

The effect of interaction between the method of udder and teat cleaning before milking and the order of forestripping on somatic cell count (SCC) and total microorganism count (TMC) in $1 \mathrm{ml}$ of milk [Die Interaktion zwischen der Methode der Zitzen- und Euterreinigung vor dem Melken und des Vormelkens auf den Gehalt an somatischen Zellen (SCC) und die durchschnittliche Keimzahl (TMC) in $1 \mathrm{ml}$ der Milch]

\begin{tabular}{l|c|c|cc|cc}
\hline \multirow{2}{*}{$\begin{array}{l}\text { Method of udder and teat } \\
\text { cleaning before milking }\end{array}$} & \multirow{2}{*}{$\begin{array}{c}\text { Forestripping is performed } \\
\text { before udder and teat cleaning }\end{array}$} & \multirow{2}{*}{$\begin{array}{c}\text { Number } \\
\text { of herds }\end{array}$} & \multicolumn{2}{|c|}{ Log $_{\mathrm{e}} \mathrm{SCC}$} & \multicolumn{2}{|c}{$\log _{\mathrm{e}}$ TMC } \\
\cline { 3 - 7 } & Yes & 17 & $12.37 \mathrm{~A}$ & 0.03 & 10.74 & 0.06 \\
\hline Dry towel & No & 23 & $12.58 \mathrm{~B}$ & 0.03 & 10.59 & 0.07 \\
\hline Wet towel with a & Yes & 17 & $12.23 \mathrm{~A}$ & 0.03 & 10.93 & 0.06 \\
disinfectant, dry towel & No & 23 & $12.49 \mathrm{~B}$ & 0.03 & 11.08 & 0.07 \\
\hline Clean water, dry towel & Yes & 23 & $12.62 \mathrm{a}$ & 0.03 & 10.94 & 0.06 \\
& No & 24 & $12.54 \mathrm{~b}$ & 0.03 & 10.85 & 0.06 \\
\hline Water with a & Yes & 27 & $12.57 \mathrm{~A}$ & 0.04 & 11.28 & 0.08 \\
disinfectant, dry towel & No & 13 & $12.25 \mathrm{~B}$ & 0.03 & 11.27 & 0.05 \\
\hline
\end{tabular}

$\mathrm{ABab}-$ Data marked with different letters are significantly different: large letters $-\mathrm{P} \leq 0.01$, small letters $-\mathrm{P} \leq 0.05$

\section{Discussion}

Similar distribution of particular methods of udder preparation for milking, which occurred in the investigated herds in spite of random selection, confirms the fact that producers do not have a definite opinion on the optimum method of udder and teat preparation for milking. Likewise in the present study, similar effects of the individual methods of cleaning the udder and teats were recently shown in Germany (FADL-ELMOULA, 2002), Poland (SKRZYPEK, 2002a) and Chile (TADICH et al., 2003). The most advantageous effect on SCC of wiping with a wet cloth and washing with water with the addition of a disinfectant certainly was a result of the fact that in both cases the udder and teats were disinfected simultaneously with being cleaned. Other authors also recommend the use of a disinfectant in the case of wiping the udder with a wet cloth (PANKEY, 1989) or washing with water (HUTTON et al., 1990). In turn, the highest SCC in the herds in which the udders and teats were washed with clean water could have been a result of the fact that in order to be washed properly, both parts of the body were subjected to the action of water for a longer period of time than in the herds in which a disinfectant was added to the water and were dried less thoroughly due to no threat of the disinfectant getting into the milk. Thus, in these herds the udder and teats were wetter at the moment the milking was initiated than in the herds where any other cleaning method was adopted. It might have created conditions resulting in more frequent disturbances in the course of milking, which in turn resulted in liner slippages and more frequent damage of the udder. SPENCER (1988), BARTLETT et al. (1992), BARKEMA et al. (1998), NAUMANN et al. (1998) and RASMUSSEN (2000) consistently reported a negative effect of disturbances during milking on health state of the udder and consequently on an increased SCC level in milk. 
Compared to the results of this study, corresponding relationships between the method of udder and teat preparation for milking and TMC were also observed by DUDKO (2001), FADL-EL-MOULA (2002) and SKRZYPEK (2002b), who showed a higher microbiological quality of milk in the herds where cleaning with a dry cloth was practiced in comparison with the herds where other methods were adopted. It is believed that a low TCM level in the milk of cows, in which cleaning the udder and teats with a dry cloth is employed, results from the fact that this method of premilking preparation inhibits the transfer of microorganisms from the central and upper part of the teat, as well as from the udder to the lower section of the teat and, as a consequence, to the milked milk (GALTON et al., 1986; RASMUSSEN, 2000; DUDKO, 2001). Moreover, RASMUSSEN and FRIMMER (1995) found that the application of disinfectants in the admissible concentration for the cleaning of teats before milking had no direct effect on the microbiological quality of milk.

The highest TMC level observed in the herds where the udder and teats were prepared for milking by being washed with water containing a disinfectant, could have been caused by the fact that water in the containers used for this purpose was replaced less frequently (or even never at all) compared with the herds in which the ordinary water was used for cleaning, and therefore it was more contaminated with microorganisms and their spores. However, it needs to be emphasized that the same method was much more effective in reducing SCC than washing with water without addition of the disinfectant. It might have been the effect of two reasons. One of them, as had been discussed before, could have been the fact that the udders washed with water containing a disinfectant were in contact with water for a shorter period of time compared to washing with clean water, and in result of this the course of milking was more proper. However, the other reason could have resulted from this that microorganisms causing udder infections are more susceptible to disinfectants than other microorganisms; especially their spores residing on the skin of the udder and teats, which are transferred to the milk during milking and multiply there after it is collected.

In our view, the reason for significant effect on SCC of the interaction between the sequence of forestripping and the method of udder and teat cleaning could have been a difference in the dryness and cleanness of the milker's hands at the moment of forestripping and the resulting differences in the exposure of cows' udders to infection. Namely, PEELER et al. (2000), RASMUSSEN (2000) and BARRETT (2002) indicated that although forestripping is potentially a very effective method of lowering the SCC in bulk tank milk, at the same time this procedure may increase the frequency of intramamary infections due to the close contact of the milker's hand with the teat. SMITH and HOGAN (1993) claimed that the milker's hands have to be both dirty and wet for the infection to spread in this way. The intergroup differences observed in this study may be explained in such a way that in the case of udder premilking preparation by wiping, the hands of the milker performing the forestripping before udder cleaning could have been dirty but dry, while the hands of the milker performing forestripping after the cows were washed could have been wet but clean, as after the direct or indirect contact with the udder of the previous cow they were washed automatically during washing the udder of the next cow. The larger difference observed in the herds in which a disinfectant was added to water in comparison to the herds where the clean water was used, was probably caused by the fact that the milker's hands, apart from 
being washed, were simultaneously disinfected. The hypothesis presented here seems to be confirmed by the fact that in contrast to SCC, the interaction between the investigated procedures of premilking udder and teat preparation did not have a significant effect on TMC. The lack of the interaction was probably caused by this that the concentration of microorganisms in bulk tank milk, which is usually assessed after a period of storage, does not have much in common with the microorganisms causing mastitis; especially with those causing the contagious mastitis, because they cannot live and multiply outside the udder.

The results of this study indicate that the udders and teats of cows should be cleaned before milking by wiping with a dry cloth or with a towel soaked with a disinfectant, and cleaning should follow forestripping. However, in the case of cleaning the udder and teats by washing with water, forestripping should be performed after cleaning.

\section{References}

BARKEMA, H.W.; SCHUKKEN, Y.H.; LAM, T.J.G.M.; BEIBOER, M.L.; BENEDICTUS, G.; BRAND, A.: Management practices associated with low, medium, and high somatic cell counts in bulk milk. J. Dairy Sci. 81 (1998), 1917-1927

BARRETT, D.:

High somatic cell counts - a persistent problem. Irish Vet. J. 55 (2002), 173-178

BARTLETT, P.C.; MILLER, G.Y.; LANCE, S.E.; HEIDER, L.E.:

Environmental and managerial determinants of somatic cell counts and clinical mastitis incidence in Ohio dairy herds. Prev. Vet. Med. 14 (1992), 195-207

BRUCKMAIER, R.M.; BLUM, J.W.:

Oxytocin release and milk removal in ruminants. J. Dairy Sci. 81 (1998), 939-949

DUDKO, P.:

The influence of the use of P3 Oxy Foam and Blu ${ }^{\circledR}$ Gard at the time of machine milking on cytological and microbiological quality of milk. Med. Weter. 57 (2001), 581-585 [in Polish, English summary]

EEC HYGIENE DIRECTIVE 89/362: Annex, 1989, chapter III, point 4

FADL-EL-MOULA, A.A.A.:

Investigations of factors affecting the udder health status of dairy cows in Thuringia. University HalleWittenberg, Diss., 2002, 124 pp.

FAHR, R.-D.:

Notwendigkeit und Grenzen der Züchtung auf Milchinhaltsstoffe und Milchqualität. Arch. Tierz., Dummerstorf 45 (2002) Sonderheft, 51-59

GALTON D.M.; PETERSSON L.G.; MERRILL W.G.:

Effects of premilking udder preparation practices on bacterial counts in milk and on teats. J. Dairy Sci. 69 (1986), 260-266

GILL, R.; HOWARD, W.H.; LESLIE, K.E.; LISSEMORE, K.: Economics of mastitis. J. Dairy Sci. 73 (1990), 3340-3348

HARMON, R.J.:

Physiology of mastitis and factors affecting somatic cell counts. J. Dairy Sci. 77 (1994), 2103-2112

HEESCHEN, W.H.:

Bestimmungsfaktoren der hygienisch-qualitativen Wertigkeit von Milch. Arch. Tierz., Dummerstorf 40 (1997) Sonderheft, 155-162

HUTTON, C.T.; FOX, L.K.; HANCOCK, D.D.:

Mastitis control practices: differences between herds with high and low somatic cell counts. J. Dairy Sci. 73 (1990), 1135-1143

MERRILL, W.G.; SAGI, R.; PETERSSON, L.G.; BUI, T.V.; ERB, H.N.; GALTON, D.M.; GATES, R.: Effects of premilking stimulation on complete lactation milk yield and milking performance. J. Dairy Sci. 70 (1987), 1676-1684

NAUMANN, I.; FAHR, R.D.; LENGERKEN, G. v.:

Zusammenhang zwischen dem Gehalt an somatischen Zellen in der Milch und ausgewählten Parametern der Milchflusskurve bei Kühen. Arch. Tierz., Dummerstorf 41 (1998), 237-250

PANKEY, J.W.:

Hygiene at milking time in the prevention of bovine mastitis. Br. Vet. J. 145 (1989), 401-409 
PANKEY, J.W.; DRECHSLER, P.A.:

Evolution of udder hygiene. Premilking teat sanitation. Vet. Clin. North Am.: Food Anim. Pract. 9 (1993), 519-530

PEELER, E.J.; GREEN, M.J.; FITZPATRICK, J.L.; MORGAN, K.L.; GREEN, L.E.:

Risk factors associated with clinical mastitis in low somatic cell count British dairy herds. J. Dairy Sci. 83 (2000), 2464-2472

RASMUSSEN, M.D.:

A review of milking preparation: the science. Proceedings of the $39^{\text {th }}$ National Mastitis Council, AtlantaMadison, 2000, 104-110

RASMUSSEN, M.D.; FRIMMER, E.S.:

The influence of premilking teat preparation on the skin microflora of the cow's teat and the hands of the milker. Forskningsrapport fra Statens Hysdyrbrugsforsøg, No. 42, 1995, 29pp. [in Danish, English summary]

SAS:

SAS $^{\circledR}$ User's Guide: Statistics. Version 5 edition (1996). SAS Inst., Cary, NC

SKRZYPEK, R.:

Somatic cell count in bulk tank milk in relation to management and technological factors. Med. Weter. 58 (2002a), 632-635 [in Polish, English summary]

SKRZYPEK, R.:

Management and technological factors affecting the microbiological quality of raw milk. Rocz. Nauk. Zoot., Suppl. 15 (2002b), 163-166 [in Polish, English summary]

SMITH, K.L.; HOGAN, J.S.:

Environmental mastitis. Vet. Clin. North Am.: Food Anim. Pract. 9 (1993), 583-595

SPENCER, S.B.:

The milking machine as a cause of mastitis. Agri-Pract. 9 (1988), 45-49

TADICH, N.; KRUZE, J.; LOCHER, G.; GREEN, L.E.:

Risk factors associated with BMSCC greater than 200,000 cells/ml in dairy herds in southern Chile. Prev. Vet. Med. 58 (2003), 15-24

WAGNER, A.M.; RUEGG, P.L.:

The effect of manual forestripping on milking performance of Holstein dairy cows. J. Dairy Sci. 85 (2002), 804-809

Received: 2003-05-22

Accepted: 2003-08-15

Authors' addresses

Priv. Doz. Dr. habil. RYSZARD SKRZYPEK

Department of Cattle Breeding

Agricultural University of Poznań

Wołyńska 33 Str.

60-637 Poznań, Poland

E-Mail: skrzypek@jay.au.poznan.pl

Prof. Dr. habil. JACEK WÓJTOWSKI

Department of Sheep and Goats Breeding

Agricultural University of Poznań

Złotniki, Słoneczna 1 Str.

62-002 Suchy Las, Poland

E-Mail: jacwoj@polbox.com

Prof. Dr. habil. ROLF-DIETER FAHR

Institute of Animal Breeding and Husbandry with Veterinary Clinic

Martin-Luther-University Halle-Wittenberg,

Adam-Kuckhoff-Str. 35

D-06108 Halle, Germany

E-Mail: fahr@landw.uni-halle.de 